ARCHIWUM FILOZOFII PRAWA

I FILOZOFII SPOŁECZNEJ

Małgorzata Król

University of Łódź

\title{
A Note on Legal Education, Its Specific Features and Related Myths
}

The question of legal education is recognised as important along various dimensions and thus has been in the focus of attention of numerous distinguished legal scholars and practitioners all over the world. The problem of legal education includes not just methodological issues, but also the issues that are par excellence philosophical in nature. Legal education has a specificity that arises from the nature of law and its complexity, and is related to the personal dimension of this education. The process of education should be organised in such a way that students should be in contact with members of the legal community whose authority, moral and subject matter-related attributes play a vital, formative role in legal education. The author tries to confront the didactics-related reality with ideals and postulates present within this field. Yet, it is revealed that such a reality is hidden below a "thick layer" of myths, which have grown around legal education. These myths blur the real picture of lawyers' education, creating a kind of legal education mythology. Two types of systemic legal myths are indicated. The first one is built on the paradigm of university legal education. The other type is based on the paradigm of university studies.

Keywords: legal education, nature and complexity of law, personal dimension in legal education, legal community, myths

\section{Why discuss legal education}

Legal education has been in the focus of attention of numerous distinguished legal scholars and practitioners all over the world. ${ }^{1}$ Thus, evidently, the question of legal education is recognised as important along various dimensions. As indicated by Adam Czarnota, ${ }^{2}$ it is legal learning and legal teaching that constitute the foundation of citizenship, a fact

There is a special interest in these issues among professors from American law schools. Cf. the rich bibliography of the subject in F. Zoll, Jaka szkota prawa? Czy amerykańskie metody nauczania prawa moga być przydatne w Polsce? [Eng. What Kind of Law School? Can American Teaching Methods Be Relevant in Poland?], Warszawa 2004, pp. 139-145; L. Wortham, C. Klein, Clinical Education and the University Mission, in: The Legal Clinic. The Idea, Organization, Methodology, ed. by The Legal Clinics Foundation, Warszawa 2005, pp. 39-43.

A. Czarnota, Kryzys nauki prawa a edukacja prawnicza. O niekonieczności produkowania „użytecznych idiotów” [Eng. The Crisis of Jurisprudence and Legal Education. On the Unnecessity of Producing "Useful Idiots"], "Prawo i Więź" 2013/2, p. 55. 
which is, however, often forgotten. Law has always been identified with the knowledge of how to apply practical reason, and, next to history, such knowledge is most important for social life.

However, sometimes the established patterns of action and routine behaviour may overshadow the need for creative thought and change in the context of legal education. There are several factors that can be indicated as operative in inducing such a change, viz. the development of the information society, the aspiration to build a civil society, as well as a change in the market situation of higher education institutions in Poland. By offering lots of ways in which one can very quickly obtain useful information related to any subject, including currently binding law, the information society in which we live promotes new challenges and invites us to build new modern and effective models of education. One of the ways in which the uniting Europe wanted to assert this fact was by starting the Bologna process. ${ }^{3}$ Leaving aside the assessment of the project and its effects, ${ }^{4}$ it should be noted that it has been the first attempt to construe a comprehensive supranational model of education at the university level with the use of technologies and cultural and civic heritage available in this part of the world.

Much as it is a trivial truth, it needs to be reasserted that educating the maximum number of people coming from different social groups is of rudimentary importance in the context of the implementation of the values and ideals of the modern Western world (as it is symbolically called). The main issue is not in obtaining formal qualifications themselves, but first of all in the high quality and level of such university education with due regard paid to European traditions and culture. Generally accessible education can have positive impact not only on the lives and social and axiological attitudes of the educated subjects, but it will also extend its influence onto the functioning of various institutions, offices, and social groups of different kinds, by which it can enhance the development of civil society.

The present changes that influence the market conditions for higher education institutions in Poland, including the phenomenon of competition ${ }^{5}$ in which the universities must participate, together with other factors, including widespread legal education, new challenges that the lawyers must face, globalism, and, what is of special importance, the noticeable crisis of institutionalised teaching of law $^{6}-$ all trigger the need to introduce reforms in the system of education.

The foundations for the procedure leading to the establishment of the European Higher Education Area were the following: the Bologna Declaration of 1988: Magna Charta Universitatum, Lisbon Recognition Convention of 1997, and the Sorbonne Declaration of 1998.

4 Assessments can be severe and taken from different perspectives. Cf. e.g. in contemporary Polish literature on the subject: L. Morawski, Przyczyny kryzysu teorii prawa [Eng. Causes of the Crisis of Legal Theory], "Przegląd Prawa i Administracji” 2015/CII, pp. 45-55.

5 Eleonora Zielińska says: "The idea of teaching law through practice fell on fertile soil in Poland in the beginning of the 90's. (...) It was also a live issue at the time of a more general debate over the traditional teaching methodology at law faculties of state schools, in particular in view of the more 'vocational' - and thus often more competitive - curricula of the newly inaugurated law faculties at private schools". E. Zielińska, Clinical education as a nucleus for the reform of legal education in Poland, in: The Legal Clinic..., p. 14.

6 Cf. e.g. in Polish literature: A. Bator, Z. Pulka, A. Sulikowski, Czy koniec teorii prawa? [Eng: Is It the End of Legal Theory?], in: P. Jabłoński (ed.), Czy koniec teorii prawa? Z zagadnień teorii i filozofii prawa [Eng: Is It the End of Legal Theory? The Problems of Theory and Philosophy of Law], Wrocław 2011, pp. 13-39; L. Morawski, Kryzys teorii prawa i innych nauk prawnych $w$ Polsce i gdzie indziej [Eng. The Crisis of Legal Theory and Other Legal Sciences in Poland and Elsewhere], "Prawo i Więź" 2013/2, pp. 60-69; A. Czarnota, Kryzys nauki prawa ..., pp. 55-56; L. Morawski, Przyczyny kryzysu..., pp. 45-55. 


\section{Specificity of legal education}

All of the above-mentioned considerations apply in their entirety to legal education. In addition, legal education has a specificity that arises from 1) the nature of law and its complexity, and is related to 2) the personal dimension of legal education.

2.1. Legal education has as its object of study law seen as a cultural phenomenon, which is manifested in normative, institutional, social, economic, and political dimensions. While reflecting on legal education, in order to facilitate conceptualisation of the object of study, we take it for granted that law constitutes an orderly autonomous system 7 with regard to other social systems, such as morality, religion, politics, or customs, even though the other axiologies are a constant source of rich inspiration for law. Law is the object both of research and of teaching at the university-type institutions, while knowledge related to law, i.e. its history, its links with social and economic institutions, certain aspects of its functioning in society, relevant values and ideals realised and postulated by the law, is contained in jurisprudence. Jurisprudence further includes the knowledge of the taxonomy and the conceptual apparatus related to law, the knowledge of the rules of legal interpretation and application of law, of legal reasoning and the rules of related exegesis. ${ }^{8}$ In the context of theoretical and legal reflection the question of the alleged scientific nature of jurisprudence ${ }^{9}$ has been posed in the methodological perspective. Jerzy Wróblewski advocates the view that this research discipline is normative ${ }^{10}$ and has impact on binding law itself and on its content. The impact that jurisprudence has on law is inalienable with regard to analysis, taxonomy and interpretation of law and its institutions performed in the course of law-related research. This fact to a certain degree reshapes the law itself (and its institutions), and, in turn, influences jurisprudence creating a new source of research for further legal studies. In this context H.J. Berman suggests that law includes the knowledge of itself, a meta-law, thanks to which it can be analysed and assessed..$^{11}$ In the contemporary theoretical and philosophical thought with general linguistic orientation, especially in its strand focused on analysis and hermeneutics, one may observe the phenomenon of the positivising of

7 This is not identical with a legal-positivist declaration, as in positivist ideology the limit of the law is demarcated by the Hartian rule of recognition, which constitutes the legal "test of origin". H.L.A. Hart, Pojęcie prawa [Eng. The Concept of Law], Warszawa 1968. Criticised by R. Dworkin, Biorac prawa poważnie [Eng. Taking Rights Seriously], Warszawa 1998. On the beliefs in this scope shared by the creators of the original positivism cf. M. Zirk-Sadowski, Wprowadzenie do filozofii prawa [Eng. An Introduction to Legal Philosophy], Kraków 2000, p. 176ff.

8 Cf. W. Lang, J. Wróblewski, S. Zawadzki, Teoria państwa i prawa [Eng. The Theory of State and Law], Warszawa 1979, pp. 7-10.

9 Cf. J. Wróblewski, O naukowości prawoznawstwa [Eng. On the Scientific Character of Jurisprudence], "Państwo i Prawo" 1965/8-9, pp. 192-203.

10 Cf. J. Wróblewski, Zagadnienia normatywności prawoznawstwa [Eng. On the Normativity of Jurisprudence], in: K. Przybyłowski et al., Rozprawy prawnicze. Księga pamiatkowa dla uczczenia pracy naukowej K. Przybytowskiego [Eng. Legal Essays. The Book Commemorating the Scientific Work of K. Przybytowski], Kraków-Warszawa 1964, p. 533ff.

11 H.J. Berman, Prawo i rewolucja. Ksztattowanie się zachodniej tradycji prawnej [Eng. Law and Revolution. The Development of Western Legal Tradition], Warszawa 1995, p. 22. The author says: "Teaching of law, to which the specialists are subjected, remains in a complex, dialectic bond with legal institutions. On the one hand, the knowledge which is being transferred describes the institutions; on the other hand what is said about them in scholarly treatises, articles and lecture rooms, serves their conceptualisation and systematisation, without which they could not constitute a coherent system. In other words, law is not composed of just legal institutions, injunctions, court decisions, etc. Law also contains what learned lawyers, but also judges and legislators, say about such institutions, injunctions and verdicts. Thus, law contains in itself the knowledge of itself, a meta-law, thanks to which it may be analysed and assessed". 
law performed within normative discourse. ${ }^{12}$ Such ideas direct our attention towards two mutually related issues.

The first issue is the question of legal dogmatic systems seen as research and educational disciplines and of their discourses related to the binding law and based on theoretical and philosophical assumptions and conclusions. In the analytic perspective, such discourses are interwoven with the discourse used within the domain of the application of law and legal practice, including delivering judgments in case law. ${ }^{13}$ In essence, there is just one discourse: "practical" discourse co-creating current binding law. ${ }^{14}$

The above-mentioned issues have relevance in the context of legal didactics as they determine that the education within the domain of jurisprudence is bound to face fundamental problems. Law itself, being the subject of the educational process, cannot be defined in an entirely technical and objective way. Law cumulates different senses, absorbs traditions, draws from external contexts, such as the linguistic, systematic, functional, or teleological domains; it puts into practice values that lawyers ascribe to or impose on the law. Law influences legal culture, which, in turn, feeds back onto law. Thus, law which is communicated, ${ }^{15}$ comprehended, and applied, but at the same time created in the process of such communication, comprehension, and application, will never in essence be as objectivised as positivists would have it be. Nor could it ever be as technical as scientists and naturalists would imagine. However, the processes active in the emergence of law within the normative discourse conducted in legal science, and the discourse of legal education, are later normally and unconsciously objectivised by lawyers who, as Jerzy Leszczyński euphemistically indicated, forget the world that they themselves create, forgetting the fact that the world is their own creation, and they refer to it as if it had an independent existence. ${ }^{16}$

Thus, the importance of legal discourse, including the above-mentioned discourse conducted in the process of legal education, can never be overestimated in the context of the essence of law itself and the participation of lawyers in the discourse with their related imagery of the world and the law. As a result, the problem of legal education includes not just methodological issues, but also the issues that are par excellence philosophical in nature. This fact is clearly demonstrated in the existing discussion focusing on the crisis in jurisprudence and legal education, which for some time has been carried on in philosophical and legal circles. ${ }^{17}$

The other problem concerns the discourse-bound image of law and relates to the participants in the normative discourse, i.e. lawyers, and their responsibility for the contents of law. ${ }^{18}$ Indeed, it is professional people to whose hands the cultivation of law is

12 Cf. J. Leszczyński, Pozytywizacja prawa $w$ dyskursie normatywnym [Eng. The Positivisation of Law in a Normative Discourse], Kraków 2010, passim.

13 "Legal practice comprises not only norms, but also legal institutions and procedures, values, concepts and ways of thinking. It comprises what is sometimes referred to as 'legal proceeding' and which in German is called Rechtsverwirklichung, that is: performing the law". H.J. Berman, Prawo i rewolucja..., p. 18.

14 Cf. J. Leszczyński, Pozytywizacja..., pp. 63-95. The author says: “...both dogmatics and legal practice compose social practice, within which establishing of the subject matter contents of the law takes place" (p. 63).

15 In the sense of social communication, i.e. a social interaction, and not in the sense of the conventional transfer of information.

16 Cf. J. Leszczyński, Pozytywizacja..., p. 16. The forgetting may result from the phenomenon of denial or from the ignorance in the field. J. Leszczyński creates a kind of a "methodological institution" of forgetting without searching for its explanation. Cf. also M. Zirk-Sadowski, Uczestniczenie prawników w kulturze [Eng. The Participation of Lawyers in Culture], "Państwo i Prawo" 2002/9, pp. 7, 11.

17 Cf. footnote 6.

18 Cf. footnote 6. See also: J. Leszczyński, Odpowiedzialność etycznozawodowa adwokatów i radców prawnych za prawo i jego autorytet [Eng. The Ethical and Professional Responsibility of Attorneys and Solicitors for Law and Its Authority], in: M. Król (ed.), Etyka adwokatów i radców prawnych. Komentarz, orzecznictwo i kazusy [Eng. The Ethics of Attorneys and Solicitors. Commentary, Court Rulings and Case Studies], Warszawa 2016, pp. 34-47. 
entrusted. ${ }^{19}$ The professional dimension is revealed through their knowledge of law and relevant conditions, their willingness to abide by the standards of professional ethics, as well as through their skills essential in practising law, viz. the techniques applicable in legal actions, legal reasoning, and other professional abilities, such as the comprehension of law, ${ }^{20}$ which altogether form a kind of legal know how. Thus, professional qualifications which constitute lawyers' essential professional equipment are related to jurisprudence. Qualifications within the above-mentioned scope can be acquired in the process of university education; they are formally certified in the form of relevant diplomas and professional degrees and titles, which serve as signs of the acquired education. Professional qualifications need to be supplemented with professional competences, i.e. practical abilities necessary for turning formal knowledge into practice and a frame of mind with readiness to meet professional expectations and tasks that are set before lawyers. Professional competences allow lawyers to practise in different settings and play various social roles in divergent fields, e.g. in business, administration, politics, science, law, etc. However, when we refer to lawyers we usually mean professionals who practise as attorneys, solicitors, prosecutors or judges. Such professionals belong to the group of people whose performance involves a position of public trust; they are people who are appointed to offer legal advice and people who are appointed to administer justice. In general, the problem of legal education is essentially a problem related to the education of lawyers who practise law. In public eyes, such professionals should demonstrate the highest level of professional competence and skills so that not only citizens' rights and interests but the law itself could be upheld.

Thus, legal competence is composed of legal knowledge supported with general humanistic and social education, as well as with professional skills, which include the ability to think like a lawyer and to comprehend law. Being professional also presupposes respecting ethical norms.

2.2. The specificity of legal education goes beyond the very nature and complexity of law. It is connected with the personal dimension present at the higher level of legal education. Apart from the desired legal qualifications and competences that can be acquired in the course of theoretical university education, there is a need for an imperative stage of legal formation, which will lead the prospective lawyer towards becoming a lawyer, a member of the legal community. The main objective of this stage is to enable graduates of legal departments to identify themselves within the relevant legal community. This aim can only be achieved where there exists a personal dimension in the process organised in such a way that students (applicants) must be in contact with members of the legal community whose authority, moral and subject matter-related attributes play a vital, formative role at this stage of legal education.

\section{Polish literature on legal education}

The above-mentioned issues lead to the conclusion that both stages of legal education, the theoretical one as well as the practical and personal one, are of equal vital importance and are both indispensable in the perspective of practising legal professions. The question which emerges is what lawyers think about legal education.

\footnotetext{
19 Cf. H. J. Berman, Prawo i rewolucja..., p. 51.

20 Cf. footnote 34.
} 
In the Polish post-war legal literature, whether focused on theory or (even more so) on legal doctrine, publications related to legal education are scarce. ${ }^{21}$ In 1981 Jerzy Wróblewski published an article in Państwo i Prawo [State and Law] entitled Modele prawoznawstwa a typy ksztatcenia prawniczego [Models of Jurisprudence and Types of Legal Education]. An extended version of the article was later re-published in a collection entitled Contemporary Models of the Legal Sciences. ${ }^{22}$ Wróblewski linked the types of legal education with the models of jurisprudence. He indicated that there were two fundamental types of legal education: a general one and a specialised one. The specialised type was subdivided into a traditional and a modern one. Application of either of the types of legal education in practice may be motivated by important factors. The general type of legal education is justified in the context of university education, i.e. education which by definition is theoretical and aims to guarantee that students become familiar with fundamental social and humanistic knowledge and with social science. This can create foundation for any further studies, including law-related studies with specific jurisprudence, i.e. with the need to provide education within the scope of methods and techniques of legal reasoning. ${ }^{23}$ This provides an excellent starting point for further, extramural and post-graduate education related to specialisation in a chosen legal profession. However, this type of education is really all about "...educating general laypeople who are not qualified to act in any legal position". ${ }^{24}$ The specialised traditional type of legal education explicitly refers to the principles of legal positivism and attempts to ground them in a relevant curriculum developed in order to secure professional training for highly qualified lawyers who will not be unfamiliar with operative knowledge of the binding law and the principles of its application, which in essence stays distinct from philosophical and social disciplines. ${ }^{25}$ The modern variant, in turn, can be characterised as an attempt to educate a "lawyer/social engineer" whose tasks can be widely defined, primarily in public administration and management, where not only legal expertise is of vital importance, but also knowledge from the fields of economy, social and technical sciences. ${ }^{26}$ In between the two models of legal education there is a whole scale of varied educational sub-types. Wróblewski's agenda was to provide links between the types of legal education and the models of jurisprudence discussed in his article, which, as the author indicated, could prove efficient in the process of defining the conception and the role of both jurisprudence and legal education. However, unfortunately, his conception was not popular and found little resonance in legal literature; neither did it motivate discussion with regard to the types of legal education in Poland. The idea of linking the models of legal sciences with types of legal education was itself criticised a few years later as lacking firm foundation and not convincing. ${ }^{27}$ Even disregarding the idea of

${ }_{21}$ In essence the same was the case at the time of the Second Polish Republic (between the First and the Second World War). Czesław Znamierowski's interests were an exception at the time as he promoted the idea of legal clinics. Cf. Cz. Znamierowski, Poradnie prawnicze [Eng. Legal Clinics], Gazeta Polska 04.10.1936, republished in: Cz. Znamierowski, O naprawie studiów prawniczych [Eng. On the Reform of Legal Studies], Warszawa 1938, cited after: Ł. Bojarski, The Social Aspect of Legal Clinics, in: The Legal Clinic..., pp. 30-32.

22 J. Wróblewski, Modele prawoznawstwa a typy ksztatcenia prawniczego [Eng. Models of Jurisprudence and Types of Legal Education], "Państwo i Prawo" 1981/4, pp. 17-29. J. Wróblewski, Contemporary Models of the Legal Sciences, Wrocław 1989, pp. 114-122.

23 Cf. J. Wróblewski, Modele ..., pp. 26-27; J. Wróblewski, Contemporary..., pp. 114-115.

24 J. Wróblewski, Modele..., p. 27.

25 Cf. J. Wróblewski, Modele..., p. 27; J. Wróblewski, Contemporary ..., p. 116.

26 Cf. J. Wróblewski, Modele..., p. 28; J. Wróblewski, Contemporary..., p. 116.

27 Cf. S. Wojtczak, Modele nauk prawnych i edukacji prawniczej wedtug Jerzego Wróblewskiego [Eng. The Models of Legal Sciences and Legal Education According to Jerzy Wróblewski], in: T. Bekrycht, M. Zirk-Sadowski (eds.), Wptyw teorii 
the discussed linkage, which seems itself rather inspiring, it is still worthwhile to use the typology of legal education presented by J. Wróblewski in the above-mentioned publication and to treat it as a starting point for a wider debate on legal education in the contemporary world.

There was an attempt to stimulate a discussion on academic legal education through the conference organised in 2002 by the Institute of Theory of State and Law of Warsaw University, entitled Funkcje nauk spotecznych i humanistycznych $w$ studiach prawniczych [The Functions of Social and Humanistic Sciences in Legal Studies]. The conference gathered many researchers representing humanities, general-social studies, and legal sciences in Poland, as well as numerous distinguished figures of social life and members of the judiciary who acted as speakers and panelists. The conference aimed to attract public attention to the need for humanistic and social education and to raise awareness with regard to the need to counteract the waning significance of such sciences in the process of lawyers' education. Simultaneously, both individual conference contributions and the general discussion revealed that the views on legal education are quite antipodal. $^{28}$

Fryderyk Zoll's 2004 publication entitled Jaka szkoła prawa? Czy amerykańskie metody nauczania prawa moga być przydatne w Polsce? [What Kind of Law School? Can American Teaching Methods Be Relevant in Poland?], ${ }^{29}$ based on rich literature, primarily of Anglo-Saxon origin, and backed with the author's own teaching experience, was an emphatic and distinct contribution to the debate on legal education. The publication included a great number of valuable insights, reliable analyses and well-documented theses. It was explicitly, and rightly, critical of the model of legal education in Poland at the time, both in terms of the model itself and the teaching methods practised. However, in this case too it proved impossible to generate wider interest in the problem in the legal community. Yet, it must be noticed that a decade later the number of critical references to the topic of legal education and its inadequate teaching model grew noticeably.

The debates focused on clinical teaching form another strand in the topic of legal education. The field of clinical education, which put down roots in Polish university legal departments in the late 1990s, is the subject of numerous recurring conferences, panels and workshops, articles and books, as well as doctoral theses. ${ }^{30}$ In general, however, clinical teaching is usually seen as the pursuit of a hobby and not a professional practice, and stays in the centre of interest for a small number of academic teachers. This is the case despite the fact that legal clinics affiliated with Polish legal departments

Jerzego Wróblewskiego na wspótczesne prawoznawstwo [Eng. The Influence of Jerzy Wróblewski's Theory on Contemporary Jurisprudence], Warszawa 2011, pp. 39-40. Cf. also an unpublished PhD thesis: M. Klauze, Nauczanie kliniczne w świetle założeń Europejskiego Obszaru Szkolnictwa Wyższego [Eng. Clinical Education in the Light of European Higher Education Area], Łódź 2015, passim.

28 The above-mentioned conference motivated the following publication: A. Turska (ed.), Humanizacja zawodów prawniczych a nauczanie akademickie [Eng. The Humanization of Legal Professions and Academic Education], Warszawa 2002, which included, inter alia, opinions presented by Zbigniew Rau (Z. Rau, Nauki społeczne i humanistyczne $w$ wyksztatceniu prawniczym z perspektywy dydaktyki doktryn polityczno-prawnych [Eng. Social and Humanistic Sciences in Legal Education in the Perspective of the Didactics of Political and Legal Doctrines], in: A. Turska (ed.), Humanizacja..., pp. 61-65) and by Wiktor Osiatyński (W. Osiatyński, Czy każdy prawnik musi być uczonym? [Eng. Is It the Case That Every Lawyer Must Be a Scholar?], in: A. Turska (ed.), Humanizacja ..., pp. 67-71).

29 F. Zoll, Jaka szkoła....

30 In 2015 Magdalena Klauze prepared and defended a PhD thesis entitled Nauczanie kliniczne w świetle założeń Europejskiego Obszaru Szkolnictwa Wyższego [Eng. Clinical Education in the Light of European Higher Education Area], supervised by M. Król, at the Department of Law Policy, Faculty of Law and Administration, University of Lódź. 
have been doing very well, which itself is rather exceptional in the European context. ${ }^{31}$ Still, the ongoing discussion among clinicians, even though quite significant, is basically limited to the problems of the functions and tasks of the legal clinics and the methods of teaching that are applied in such clinics. ${ }^{32}$ Some of the suggestions and conclusions may, however, be of a more universal value and may be found to be applicable in the discussion on legal education as such.

\section{Myths related to legal education}

\subsection{The need for the reconstruction of myths}

It is clear that legal education is significant for social life and that there is a need for reform with regard to legal didactics. In this context there emerges the question of proper direction of such a reform. It is easier to define such a direction on the basis of critical analysis of the Polish model of legal education. The existing expectations with regard to legal education result partly from its specificity. It is, therefore, practical to confront the didactics-related reality with ideals and postulates present within the field. Yet, it will soon be revealed that such a reality is hidden below a "thick layer" of myths, which have grown around legal education. Those myths blur the real picture of lawyers' education, creating a kind of legal education mythology. The collection of myths promotes a formal and superficial model of education, which makes the need for reform less evident. Below, I am trying to reconstruct myths abounding in legal education, basing this reconstruction on my personal many years' experience as an academic teacher. I am going to identify two types of systemic legal myths. The first one is built on the paradigm of university legal education. The other type is based on the paradigm of university studies. The legal mythology that is being reconstructed here does not concern clinical teaching, where different educational standards and principles are applied and which is subject to its own distinct mythology, which in turn deserves separate attention.

\subsection{The myths based on the paradigm of university legal education}

Myths of the type are based on the sacred tradition of the university system of education, within which university is understood as an institution of higher education and research, primarily devoted to scientific reflection, and where a wide array of students

31 The question of the causes of such a spectacular success of legal clinics in Central and Eastern Europe remains to be investigated and is often the subject of debate during conferences, panels and workshops. Recently, it was discussed during the Workshop on Clinical Legal Education at the Dickson Poon School of Law, King's College London on 9 February 2016.

32 In Polish literature, e.g.: E. Zielińska, Klinika Prawa - Uniwersytecka Poradnia Prawna [Eng. The Legal Clinic - University Legal Counselling], "Klinika” 1999/1, pp. 219-221; M. Szewczyk, Idea uniwersyteckich poradni prawnych [Eng. The Concept of Students Legal Clinics], "Klinika" 1999/1, pp. 13-18; Studencka Poradnia Prawna. Idea, organizacja, metodologia [Eng. The Legal Clinic. The Idea, Orgnization, Methodology], ed. by Fundacja Uniwersyteckich Poradni Prawnych, Warszawa 2005 and the literature quoted therein; The Legal Clinic... and the literature quoted therein; Ł. Bojarski, B. Namysłowska-Gabrysiak, Symulacja rozpraw sqdowych jako metoda edukacyjna [Eng. Moot Court as a Teaching Method], Warszawa 2008; B. Namysłowska-Gabrysiak (ed.), Studencka poradnia prawna. Kompendium dla studentów [Eng. The Legal Clinic. Textbook for Students], Warszawa 2008; B. Namysłowska-Gabrysiak (ed.), Studencka poradnia prawna. Podręcznik dla opiekunów [Eng. The Legal Clinic. Textbook for Supervisors], Warszawa 2009; M. Król (ed.), Etyka zawodów prawniczych. Metoda case study [Eng. The Ethics of Legal Professions. The Case Study Method], Warszawa 2011; M. Król (ed.), Opinie prawne w praktyce [Eng. Legal Opinions in Practice], 2nd ed., Warszawa 2015. 
can acquire knowledge through a specific university method, i.e. lecture. The Polish paradigm of legal education represents this university character par excellence, with all its positive and negative aspects. We should confront it with the professional system, which is applied, for instance, in American law schools. ${ }^{33}$ The university system is principally revealed in the theoretical, humanistic and social profile of the subjects taught and lectured together with the basic didactic method applied, i.e. a lecture delivered, non-metaphorically, ex cathedra. Thus, the myths of the type have been reconstructed on the basis of the existing tradition of university teaching, the curricula of legal studies and the applied didactic methods, which together jointly form the university paradigm of legal education.

\subsubsection{The myth of teaching the comprehension of law 34}

The myth of teaching the comprehension of law deserves special attention and should be clearly exposed. Practicing law is to a certain degree connected with social and legal maturity, which can hardly be expected from students. It is also connected with having imagination and readiness to provide legal aid, to accept professional and moral responsibilities, and to face various types of difficulties which can occur in a lawyer's life.

The comprehension of law is an extremely broad notion. It pertains to grasping law in all its complexity as a normative, linguistic, social, and axiological phenomenon..$^{35}$ It is about seeing the significance and the role of law in the society, seeing its limitations and potential, being aware of legal ideologies and their impact on the application of law, seeing the bond between law and morality and values. The comprehension of law further comprises legal awareness and attitudes towards law, and understanding of the role and social functions of legal professions. It also involves understanding of the mechanisms that stand behind actions in a pluralist civil society, the rules of democracy, the institution of state sovereignty, etc. ${ }^{36}$ Understanding law also means being able to identify the problems which arise within the above-mentioned areas and being able to solve such problems. It comprises excellent command of the legal conceptual system and the ability to use it correctly in practice, both in the sphere of private and public law and in local and supranational contexts. Apart from that, it also means understanding the mechanisms of the application of law, of legal institutions, and the process of law coming into being in the course of legal argumentation. ${ }^{37}$ It must further be noticed that practically every sphere of law and each legal institution rests upon an axiological foundation. As a result, legal dogmatics are in a sense a special case of legal philosophical and ethical considerations and are far from the axiological neutrality promoted by, e.g., legal positivism. The comprehension of law must then also mean resistance to the stance of moral indifference in relation to law, its institutions and effects of its application. The source of such an indifference can be seen in "cynical legal education" (to follow

33 Cf. F. Zoll, Jaka szkota ..., pp. 47-89.

34 This myth does not, strictly speaking, refer to the resignation in a wider scope from teaching hermeneutics as a philosophy of understanding law; legal hermeneutics ideas constitute in fact an important inspirational factor with regard to the understanding of law.

35 On different research-related aspects of jurisprudence, both ontological and methodological: cf. K. Opałek, J. Wróblewski, Zagadnienia teorii prawa [Eng. The Problems of Legal Theory], Warszawa 1969, pp. 326-334.

36 Cf. Z. Rau, Nauki spoteczne..., pp. 62-63.

37 Cf. references to the philosophy of comprehension of law according to Arthur Kaufmann in: M. Zirk-Sadowski, Wprowadzenie..., p. 91. 
the phrase suggested by K. Economides ${ }^{38}$ ) practised sometimes by legal teachers. In the process of education, teachers typically apply a quasi-positivist method of presenting law. This is partly connected with the didactic need to objectify law as a subject being taught and place a boundary between the teacher of law as an instructor and law itself - a subject which is being taught. This type of a quasi-positivist educational method is rather useful and comfortable in legal education for presenting law and its institutions. In the course of teaching, however, the educators forget to explicate relevant caveats with regard to the image of law which emerges when this method is applied, the method which distorts the real picture of law and gives rise to a legal myth.

In the long run, teaching law without its proper understanding by students can produce disastrous effects in all spheres of social life. In general, it leads to ignorance with regard to the knowledge of the mechanisms operating in social and legal life on the part of prospective lawyers. Within the canon of subjects accepted for legal curricula, each subject on its own contains material which is formally essential for the successful realisation of its didactic aim, i.e. teaching how to comprehend law. However, the practised model of legal education does not help proper realisation of the intended end. This primarily results from the fact that particular branches of law and the contents of legal institutions are presented in isolation. There is a lack of a holistic perspective on legal phenomena and of the demonstration of the acts of law in practice. Just like in nearly the entire system of schooling, including higher education, the students acquire encyclopaedic knowledge, usually without the ability to put it into practice.

\subsubsection{The myth of teaching to think like a lawyer ${ }^{39}$}

This is one of the most fundamental and widespread myths concerning legal education in Polish university law departments. Based on entirely false premises, it is connected with an unjustified belief that, in the course of studies, legal students acquire systematic theoretical knowledge about law, and not just about the contents of provisions included in statutes. Secondly, the myth is connected with the belief that students are taught the techniques of legal action, legal reasoning, and professional skills. In fact in the curriculum of legal studies there is no such course as "legal methods" and usually there is no obligatory course of the type of "legal writing" or even one about drafting procedural documents. ${ }^{40}$ Isolated elements of that kind may indeed be found in the context of various lectures (e.g. theory and philosophy of law includes a discussion on the methodology of jurisprudence) or workshops (e.g. within seminars on legal dogmatics), but they do not form an integrated whole. Methodology and specific methods are one of the elements thanks to which research disciplines can be distinguished (vide sociological or psychological methods). In the course of legal studies it is common to refer to legal methods and techniques, but students are not taught the ability to solve legal problems. They do not practise argumentation techniques or negotiation skills and are not taught mediation despite the fact that alternative dispute resolution methods are

38 This leads to a tacit agreement that lawyers can manipulate law, abuse it with evil intentions, apply the law dishonestly. Economides' wording: cynical legal education is cited after: A. Czarnota, Kryzys nauki prawa ..., p. 52.

39 The definition of the method/methods of teaching to think like a lawyer is cited after F. Zoll, Jaka szkota ..., p. 60 , fn. 63 where it is mentioned in the context of a discussion on the dialogic method of interacting with students which is applied in American law schools.

40 There are workshops focusing on this field organised in the legal clinic in Łódź. The Faculty of Law and Administration of the University of Lódź also holds optional courses on drafting court documents in the field of criminal law. 
procedurally lawful; they do not practise the interpretation of law or legal reasoning. Law students do not have any opportunity to think like a lawyer in the course of legal studies because they do not role-play any court proceedings. They are not required to produce legal opinions, they are not taught any interpersonal communication skills - including how to conduct a conversation with a client (although students in the legal clinic in Łódź learn this) and they are not taught many other skills useful for a lawyer which shape a person's ability to think like a lawyer. ${ }^{41}$ We remain, therefore, within the sphere of wishful thinking and myths. The reasons for this unsatisfactory state of affairs can be attributed to narrow specialisation fields, segmentation and fragmentation of legal science as taught to students, that is divided into a large number of didactic courses following the research interests of particular academic teachers, ${ }^{42}$ and the lack of a holistic perspective ${ }^{43}$ on law together with a failure to apply problem-focused teaching.

\subsubsection{The myth of educating (shaping) lawyers/humanists}

Legal studies fall within the category of arts, within humanities and social studies. Lawyers' general education can be important in many different ways. First of all, it forms the necessary foundation for rational, conscious action, and broadens the mind. ${ }^{44}$ It also allows people to see the diversity present in the world in every dimension, ${ }^{45}$ it shapes attitudes, builds social and moral sensitivity, raises awareness with regard to other people's affairs. Lech Gardocki, a former First President of the Supreme Court, found a picturesque way to define the general humanistic knowledge that each lawyer should have, naming it as disinterested. Such knowledge, in the judge's opinion, is essential for lawyers, and "[w]ithout this disinterested knowledge they will just be craftsmen of law, being constantly aware of their incompetence in matters which go beyond their professional sphere; one-dimensional people without a chance of acquiring lasting prestige in the society and exerting real impact on how the society in which we live functions". ${ }^{46}$

41 With reference to clinical education Prof. Leah Wortham and Prof. Catherine Klein of Catholic University of America in Washington say that teaching a student to act like a lawyer includes: "This is how we do it here" but also answering the question: "What is the consequence of doing it this way - for specific clients, for groups of clients, for the justice system, for the lawyers themselves?" or "Whose interests are served by doing this this way?" and "How might this be done better?”. L. Wortham, C. Klein, Clinical Education ..., p. 37.

42 Cf. Hubert Izdebski, who poses a rhetorical question: “...is it that science and didactics must follow the same paths, rest upon the same principles, including specialisation, which is already well advanced in science?" H. Izdebski, Podsumowanie konferencji [Eng. The Summary of the Conference], in: A. Turska (ed.), Humanizacja ..., p. 96.

43 Similar things happen in other sciences - vide medicine with its very narrow fields of specialisation and a lack of a holistic perspective on the human being.

44 A different perspective on the problem is taken by W. Osiatyński, who says: "I firmly believe that the factors that build broad horizons and interests are the secondary school, the parents, and only then, for some people, one exceptional professor. Someone they came across. In contrast, it is unlikely that someone is going to have broad horizons thanks to their deep study of a subject (...). Broad horizons are developed through upbringing, through education, through acculturation, through passion, but not through the fact that someone has passed an exam in state and law or in the history of political and legal doctrines”. W. Osiatyński, Czy każdy prawnik..., p. 68.

45 "Although knowledge does not guarantee moral conduct, it does broaden the mind and prevents the development of intolerant attitudes. Thanks to philosophical knowledge, one receives a closer spectrum of possible attitudes. Another barrier for intolerance may be formed by the awareness of the fact that there are many justifiable points of view. It is evident that a judge, a politician, or a journalist who is filled with fanaticism may bring much harm to the society. In addition, tolerance instilled by philosophy is in an organic way interwoven with democracy, which at present we are to shape in Poland, considering that it is the best system". M. Szyszkowska, Niezbędnośc filozofii i filozofii prawa w ksztatceniu prawniczym [Eng. The Necessity of Philosophy and Legal Philosophy in Legal Education], in: A. Turska (ed.), Humanizacja..., pp. 18-19.

46 L. Gardocki, Funkcje nauk humanistycznych $w$ studiach prawniczych [Eng. The Role of Humanities in Legal Studies], in: A. Turska (ed.), Humanizacja..., p. 146. 
With the use of this neat rhetorical figure, lawyers' general humanistic knowledge can indeed be termed disinterested. However, the virtue of good humanistic education for lawyers is necessary from a social point of view as in every society there is a need for enlightened lawyers. Quite to the contrary, therefore, humanistic knowledge which lawyers should possess is a kind of par excellence "interested" knowledge in public eyes.

Is it the case that contemporary legal studies educate lawyers/humanists? Law students and graduates in most cases identify themselves as humanists, but they use the term in its ordinary meaning, indicating that they belong in arts and are not gifted in the field of science. It is just a myth, however, that legal studies educate humanists in the original sense of the word, i.e. that they instil in students the ability to understand the world around them, teach them to uphold what is right in this world, allow them to raise awareness and sensitivity in relation to individual and social problems. Although legal studies curriculum includes content related to the general knowledge of humanistic and social issues, these are presented in an entirely ineffective way from a didactic point of view. This is why enlightened lawyers who are sensitive to social and human values, thinking and understanding humanists active in various legal professions, in general tend not to be a "product" of successful legal education in the field - they simply owe the merit to themselves.

\subsubsection{The myth of lawyers' ethical awareness (ethical emotions)}

For a couple of decades immediately following World War II, teaching legal ethics was considered redundant in Poland. There was a number of factors underlying that attitude, some of which must have been political, but the situation was apparently also related to a rather primitive understanding of the legal-positivist model of practicing jurisprudence. It translated into the style and the model of legal education which have in fact remained to this day. ${ }^{47} \mathrm{I}$ believe, possibly in a naïve way, that the situation was also justified with a belief in natural intuition and lawyers' moral awareness. Nowadays, the situation is undergoing gradual change thanks to the introduction of courses in professional ethics into legal studies curricula, which more and more often, especially in clinical teaching, are obligatory. However, at the legal faculties one can still sense the attitude of disregard towards the subject. And yet the law absorbs lawyers' moral attitudes. The professional should perform his or her professional duties honestly and ethically as otherwise he or she will corrupt law; even fair and equitable law may turn to be immoral when it is abused and applied in an immoral and dishonest way. In order to shape positive ethical emotions it is not yet enough that a lecture on ethics is introduced in the course of legal studies. It is also essential that such a lecture be complemented with interactive methods of teaching professional ethics. ${ }^{48}$ There is a very good and effective didactic instrument which can be used in order to comprehensively familiarise students with problems of ethics in the form of the pervasive method, ${ }^{49}$ which,

47 Cf. a similar reflection in: A. Czarnota, Kryzys nauki prawa..., pp. 51-52.

48 Cf. e.g. M. Król (ed.), Etyka zawodów..., pp. 46-61.

49 For a discussion on the pervasive method (in Polish, apart from metoda perwasywna, ethics specialists also use the term metoda perwazywna - which, however, seems less adequate), cf. e.g. P. Skuczyński, Pervasive method w edukacji etycznej a kierunki badań w etyce prawniczej [Eng. The Pervasive Method in Ethical Education and the Direction of Research in Legal Ethics], in: H. Izdebski, P. Skuczyński (eds.), Edukacja etyczna prawników - cele i metody [Eng. The Ethical Education of Lawyers - Goals and Methods], Warszawa 2010, p. 61ff., who also further discusses the hazards of the application of this method on the part of academic teachers who have not been prepared for practising it: pp. 66-68. 
however, is rather difficult for lecturers. This method involves introducing ethical issues in the course of discussing particular legal norms and institutions at all levels of legal education. It allows students to become aware of ethical problems and dilemmas accompanying the application of law, teaches them how to solve such problems, and also raises ethical awareness and shapes correct ethical attitudes in law students. It further allows for instilling in the young aspiring lawyers' and law students' minds the belief that "...legal ethics is an indispensable element of legal practice." 50

\subsection{The myths based on the paradigm of university studies}

\subsubsection{The myth of legal studies as non-difficult studies}

There is a common opinion that any person, irrespective of the lack of special abilities, can easily manage legal studies as long as the person has good memory and "is talkative". This is true to some extent, mainly due to the accepted rules of legal studies, the form in which students are taught (e.g. optional lectures, interactive classes, seminars, or monographic lectures often credited on the basis of the student's attendance) and, in general, due to the low expectations with regard to students' performance by academic teachers. A similar belief functioned in public opinion in the pre-war period. ${ }^{51}$ The myth of easy legal studies results mainly from a belief in the humanistic character of such studies, taken in a simplified and vulgarised way, and juxtaposed with science studies at technical and natural science faculties, which "require thinking" and certain abilities. Naturally, legal studies have a humanistic and a social dimension if the context in which law functions is to be considered together with the nature of the legal phenomenon and with the social and humanistic character of the functions that lawyers perform. However, this dimension, if it is to be treated seriously, requires a significant cognitive effort from all persons engaged in the didactic process, requires their time and attention in order to be able to meet the requirements connected with educating "an enlightened lawyer". It primarily requires demonstrating the complexity of law, its identity and autonomy, irrespective of the presence of numerous normative systems which make up the context for the functioning of law. It also demands teaching the history of law and social mechanisms and, finally, teaching students to think like lawyers.

\subsubsection{The myths of studying}

It is a myth that students study. The term 'to study', when taken sensu proprio means to analyse, to deliberate, to investigate, to explore, to broaden one's knowledge, to examine, to delve into consideration, to wonder, while the term 'student' indicates the one who studies. ${ }^{52}$ It does not happen very often that students of law study. However, it is

50 P. Skuczyński, Pervasive method..., p. 66.

51 H. Izdebski, concluding a 2002 conference devoted to academic teaching, claimed the following: "[I]t may indeed appear to some people that law is easy, simple and entertaining. If only time allowed, I would read a fragment from Claude Levi-Strauss's diary, where he explained why he studied law in the 30s in Paris. And the reason he did it was that the studies were easy and simple, something in between theology and journalism, and he was able to prepare for exams and to easily pass them within fifteen days. It is not until, and this is actually the whole misery of legal studies, the time when one must face real problems of the law that it is revealed how many of the so-called additional qualifications are necessary in order to have true qualifications in the discipline". H. Izdebski, Podsumowanie..., pp. 99-100.

52 Cf. Maty stownik języka polskiego [Eng. Small Polish Dictionary], Warszawa 1993, p. 890. 
also a fact that nobody demands from them that they do it. At this point it is relevant to refer back to the above-mentioned myths concerning easy legal studies. The above remarks are generalisations, not always justified. And yet, in statistical terms, the mass-scale provision of legal education leads to the lowering of academic standards.

\subsubsection{The myth of legal qualifications possessed by graduates of legal departments}

This myth is an effect of the functioning of myths based on the paradigm of university legal education, including learning to think like a lawyer. Both graduates of legal departments and employers realise that legal qualifications certified only with a master's degree are in fact illusory. The reason is that university law school may provide students with some information about law but it does not teach law. It does not prepare them to practise law, neither does it equip them with those indispensable legal skills which happen to be universal. This fact confirms the thesis that further legal formation is necessary in order to turn a graduate into a lawyer. At present, modern legal education requires taking into account that lawyers' situation in the European Union and in the world is changing, and that there is a need for educating universal lawyers who can move from place to place and who have at their disposal competences that allow them to practise law anywhere. This would be possible if they were taught legal competences and not only offered information about the binding legal provisions hic et nunc.

\section{Conclusions}

The myths enumerated above create a kind of mythological image of legal education. They are like pieces of a jigsaw puzzle, which enable us to form a visible picture of legal teaching. This picture, however, does not allow us to see what is invisible prima facie. The task to notice and critically analyse the invisible is left to legal academics.

It was not my aim to create a model, or a number of models, of legal education, primarily due to the fact that such models should emerge out of a wide discussion within the legal community, which would result in working out of a relevant consensus. Starting a discussion on the subject is both worthwhile and necessary. 


\section{BIBLIOGRAFIA / REFERENCES:}

Bator, A., Pulka, Z., Sulikowski, A. (2011). Czy koniec teorii prawa? In: P. Jabłoński (Ed.), Czy koniec teorii prawa? Z zagadnień teorii i filozofii prawa. Wrocław: Wydawnictwo Uniwersytetu Wrocławskiego.

Berman, H.J. (1995). Prawo i rewolucja. Ksztaltowanie się zachodniej tradycji prawnej. Warszawa: PWN.

Bojarski, Ł., Namysłowska-Gabrysiak, B. (2008). Symulacja rozpraw sądowych jako metoda edukacyjna. Warszawa: C.H. Beck.

Czarnota, A. (2013). Kryzys nauki prawa a edukacja prawnicza. O niekonieczności produkowania „użytecznych idiotów”. Prawo $i$ Więź 4(2), 48-59.

Dworkin, R. (1998). Biorac prawa poważnie. Warszawa: PWN.

Hart, H.L.A. (1998). Pojęcie prawa. Warszawa: PWN.

Izdebski, H. (2002). Podsumowanie konferencji. In: A. Turska (Ed.), Humanizacja zawodów prawniczych a nauczanie akademickie. Warszawa: Wydawnictwo Liber.

Klauze, M. (2015). Nauczanie kliniczne w świetle założeń Europejskiego Obszaru Szkolnictwa Wyższego. Unpublished Ph.D. thesis.

Lang, W., Wróblewski, J., Zawadzki, S. (1979). Teoria państwa i prawa. Warszawa: PWN.

Leszczyński, J. (2010). Pozytywizacja prawa w dyskursie normatywnym. Kraków: Universitas.

Leszczyński, J. (2016). Odpowiedzialność etycznozawodowa adwokatów i radców prawnych za prawo i jego autorytet. In: M. Król (Ed.), Etyka adwokatów i radców prawnych. Komentarz, orzecznictwo $i$ kazusy. Warszawa: C.H. Beck.

Morawski, L. (2013). Kryzys teorii prawa i innych nauk prawnych w Polsce i gdzie indziej. Prawo $i$ Więź $4(2), 60-69$.

Morawski, L. (2015). Przyczyny kryzysu teorii prawa. Przeglad Prawa i Administracji 52, 45-54.

Namysłowska-Gabrysiak B. (Ed.). (2008). Studencka poradnia prawna. Kompendium dla studentów. Warszawa: Wolters Kluwer.

Namysłowska-Gabrysiak B. (Ed.). (2009). Studencka poradnia prawna. Podręcznik dla opiekunów Warszawa: Wolters Kluwer.

Opałek, K., Wróblewski, J. (1969). Zagadnienia teorii prawa. Warszawa: PWN.

Osiatyński, W. (2002). Czy każdy prawnik musi być uczonym? In: A. Turska (Ed.), Humanizacja zawodów prawniczych a nauczanie akademickie. Warszawa: Wydawnictwo Liber.

Rau, Z. (2002). Nauki społeczne i humanistyczne w wykształceniu prawniczym z perspektywy dydaktyki doktryn polityczno-prawnych. In: A. Turska (Ed.), Humanizacja zawodów prawniczych a nauczanie akademickie. Warszawa: Wydawnictwo Liber.

Skuczyński, P. (2010). Pervasive method w edukacji etycznej a kierunki badań w etyce prawniczej. In: H. Izdebski, P. Skuczyński (Eds.), Edukacja etyczna prawników - cele i metody. Warszawa: Instytut Etyki Prawniczej.

Studencka Poradnia Prawna. Idea, organizacja, metodologia (2005). Warszawa: Fundacja Uniwersyteckich Poradni Prawnych. 
Szewczyk, M. (1999). Idea uniwersyteckich poradni prawnych. Klinika 1, 13-18.

Szyszkowska, M. (2002). Niezbędność filozofii i filozofii prawa w kształceniu prawniczym. In: A. Turska (Ed.), Humanizacja zawodów prawniczych a nauczanie akademickie. Warszawa: Wydawnictwo Liber.

Turska A. (Ed.). (2002)., Humanizacja zawodów prawniczych a nauczanie akademickie. Warszawa: Wydawnictwo Liber.

Wojtczak, S. (2011). Modele nauk prawnych i edukacji prawniczej według Jerzego Wróblewskiego. In: T. Bekrycht, M. Zirk-Sadowski (Eds.), Wpływ teorii Jerzego Wróblewskiego na wspótczesne prawoznawstwo. Warszawa: C.H. Beck.

Wortham, L., Klein, C. (2005). Clinical Education and the University Mission. In: The Legal Clinic. The Idea, Organization, Methodology. Warszawa: The Legal Clinics Foundation/C.H. Beck.

Wróblewski, J. (1964). Zagadnienia normatywności prawoznawstwa. In: W. Osuchowski, M. Sośniak, B. Walaszek (Eds.), Rozprawy prawnicze. Księga pamiatkowa dla uczczenia pracy naukowej $K$. Przybyłowskiego, Kraków-Warszawa: PWN.

Wróblewski, J. (1965). O naukowości prawoznawstwa. Państwo i Prawo 8-9, 192-203.

Wróblewski, J. (1981). Modele prawoznawstwa a typy kształcenia prawniczego. Państwo i Prawo 4, 17-29.

Wróblewski, J. (1989). Contemporary Models of the Legal Sciences. Wrocław: Ossolineum,

Zielińska, E. (1999). Klinika Prawa - Uniwersytecka Poradnia Prawna. Klinika 1, 219-221.

Zielińska, E. (2005). Clinical education as a nucleus for the reform of legal education in Poland. In: The Legal Clinic. The Idea, Organization, Methodology. Warszawa: The Legal Clinics Foundation/C.H. Beck.

Zirk-Sadowski, M. (2000). Wprowadzenie do filozofii prawa. Kraków: Zakamycze.

Zirk-Sadowski, M. (2002). Uczestniczenie prawników w kulturze. Państwo i Prawo 9, 3-14.

Zoll, F. (2004). Jaka szkoła prawa? Czy amerykańskie metody nauczania prawa moga być przydatne w Polsce? Warszawa: Dom Wydawniczy ABC. 